\title{
SALINITY EFFECTS ON GERMINATION, GROWTH AND MINERAL NUTRITION OF RICINUS COMMUNIS SEEDLINGS
}

\author{
K. Makhlouf ${ }^{1,2}$, L. Hamrouni ${ }^{2}$, M. L. Khouja ${ }^{2}$ and M. Hanana ${ }^{3}$ \\ ${ }^{1}$ Faculté des Sciences de Tunis, Campus Universitaire, 2092 El Manar II, Tunisie \\ ${ }^{2}$ Laboratoire d'Ecologie Forestière, Institut National de Recherches en Génie Rural \\ Eaux et Forêts, IRESA, Université de Carthage, P. O. B. 10, 2080 Ariana, Tunisie \\ ${ }^{3}$ Laboratoire de Physiologie Moléculaire des Plantes, Centre de Biotechnologie de Borj-Cédria \\ BP 901, 2050 Hammam-lif, Tunisie; E-mail: punto80@yahoo.com
}

(Received 11 April, 2014; Accepted 25 July, 2014)

\begin{abstract}
The salinity effects on the germination and the growth of greenhouse grown castor bean (Ricinus communis L.) from three local provenances (Sidi Thabet, Grombalia and Kairouan) were studied. Plants were grown in sand-perlite mixture and irrigated with solution containing $0,2,5$, and $10 \mathrm{~g} / \mathrm{l} \mathrm{NaCl}$. The effect of salt stress on germination was weakly pronounced in the case of castor bean for the three provenances compared to control. Moreover, salt stress induced significant differences on plant growth during the experimental period. After 80 stress days, decreases in plant height were observed. $10 \mathrm{~g} / \mathrm{l} \mathrm{NaCl}$ has an intense depressive effect on seedling stage. The seedlings have not completed their development and this is noticed for all provenances. $5 \mathrm{~g} / 1 \mathrm{NaCl}$ has also an intense depressive effect only for Grombalia. With regards to the mineral nutrition, hypocotyls are more concentrated in $\mathrm{Na}^{+}$and $\mathrm{Cl}^{-}$than the other organs. Thus, we observed a slight increase in $\mathrm{K}^{+}$ concentration for 2 and $5 \mathrm{~g} / \mathrm{l} \mathrm{NaCl}$ compared to control, especially for Kairouan in stems. Based on the stability of the tolerance to salinity from germinative stage to seedlings stage, the provenance of Kairouan was identified as the most tolerant and the provenance of Grombalia as the most sensitive to salt toxicity.
\end{abstract}

Key words: germination, $\mathrm{Na}^{+}$and $\mathrm{Cl}^{-}$, Ricinus communis, salinity tolerance, salt stress, seedlings

\section{INTRODUCTION}

Ricinus communis L., also known as castor bean, grows in many parts of the world like Africa, Asia and America. It is an oilseed plant with oil content between $40 \%$ and $60 \%$ in commercial varieties (Weiss 1983). Castor bean is a crop plant of commercial relevance since its oil is used for manufacturing surfactants, coatings, greases, fungistats, pharmaceuticals, cosmetics, and many other products (Pinheiro et al. 2008). In addition to commercial relevance, Rici- 
nus communis has a therapeutic property. Leaves have been used for treatment of rheumatics and as antibacterial and anti-inflammatory (de la Paz et al. 2006, Luseba et al. 2007). The roots have also been used for laxative and the treatment of inflammation and liver disorders (Ilavarasan et al. 2005). In spite of the increased interest in castor oil, the world production of castor seeds remains relatively low compared to the other oilseed crops. In Tunisia, Ricinus communis is not yet grown. We can find many wild populations across the territory. As well, the Mediterranean bio-climatic regions are frequently irrigated with salt water. So, about $10 \%$ of the whole territory and $20 \%$ of the cultivated lands are saline (Ben Ahmed et al. 2008) and about 15 million hectares are affected by salinity in the Maghreb and the Middle East. Moreover, the majority of the arable lands are reserved for the field crops, such as that of cereals and leguminous since salinity is the major environmental factor limiting productivity (Allakhverdiev et al. 2000). Furthermore, drought stress periods and limited irrigation may lead to progressive salinisation of the lands, mainly due to $\mathrm{NaCl}$ accumulation in soils, exposing crops to salt stress conditions. Salinisation constitutes an important environmental factor limiting crop growth and yield (Ashraf 2004, Xiong et al. 2002). Consequently, the continued salt accumulation in the soils results in considerable changes in many physiological processes of the plants, such as ion toxicity, decreased growth and changes in mineral distribution (Mansour and Salama 2004). In the following study, salt tolerance of Ricinus communis L. from 3 local stations was examined at the germination and seedlings growth stages to identify potential tolerant provenance.

\section{MATERIALS AND METHODS}

\section{Plant material}

Seeds were collected in 2008 from three natural habitats of Ricinus communis (Sidi Thabet, Grombalia and Kairouan). The climatic conditions prevailing in each region were considered. Also, it should be noted that there is morphological difference in seeds between the three provenances (Table 1). Before the germination tests, damaged and insect infected seeds were discarded, and the empty ones were eliminated using the floating method in distilled water. Seeds were separated from fruits and soaked in water for $24 \mathrm{hr}$. These seeds were sterilised with Benlate $(1 \mathrm{~g} / \mathrm{l})$ for $20 \mathrm{~min}$, then with sodium hypochlorite $50 \%$ for few minutes and rinsed three times with distilled water. 
Table 1

Morphological diversity of seeds and climate variability of the three provenances

\begin{tabular}{lcccc}
\hline Bioclimatic & $\begin{array}{c}\text { Annual pluvio- } \\
\text { metry }(\mathrm{mm})\end{array}$ & $\begin{array}{c}\text { Temperature } \\
\left({ }^{\circ} \mathrm{C}\right)\end{array}$ \\
Sidi Thabet & subhumid & $450-500$ & 18.7 \\
Kairouan & semiarid & $250-400$ & $\begin{array}{c}5-21 \\
(\text { winter })\end{array}$ \\
Grombalia & semiarid & $390-630$ & $\begin{array}{c}19.2 \\
(\text { summer })\end{array}$ & \\
\hline
\end{tabular}

\section{Salinity treatments}

Germination tests were performed in pots filled with soil and inert substrate (Perlite). Experiments were carried out in controlled conditions in a glasshouse at $25^{\circ} \mathrm{C}$, relative humidity of $80 \%$ with a natural sunlight. The experiment was laid with 4 salt treatments including control and each treatment was replicated three times. The saline treatments used were 0 (control), 2, 5 and $10 \mathrm{~g}$ of $\mathrm{NaCl}$ added to one litre of distilled water. Salt stress was induced from the first day of planting. During germination stages, seeds in all treatments were irrigated with $15 \mathrm{ml}$ daily. After that, seedlings were irrigated 3 times a week, with a Knop's solution added by various concentrations of $\mathrm{NaCl}$.

\section{Germination rate}

Mean time of germination (MTG) and the parameters of germination speed were also calculated for supplementary explanations. MTG was calculated as follows:

$$
\mathrm{MTG}=\sum \mathrm{n}_{\mathrm{i}} \times \mathrm{d}_{\mathrm{i}} / \mathrm{n},
$$

where " $n$ " is the total number of germinated seeds during the germination test, " $n_{i}$ " is the number of germinated seeds on day " $d_{i}$ " and " $i$ " is the number of days during the germination period (between 0 and 45 days) (Yousheng and Sziklai 1985). Germination counts were performed daily for 45 days and 
germination was considered to have occurred if the radicle protruded $2 \mathrm{~mm}$ from the seed coat (Edwards and Wang 1995). Cumulative germination percentage (GP \%) was evaluated daily and the final value was obtained after 45 days and Kotowski's coefficient $(\mathrm{CV})$ was calculated according to this method:

$$
\mathrm{CV}=\sum(\mathrm{n} \times \mathrm{Jn}) / \sum \mathrm{n}
$$

Besides, the plants cultivated in pots under greenhouse were the object of another assay.

\section{Vegetative growth}

At the end of the experimental period, surviving plants were carefully removed from the substrate, washed with distilled water and separated in different organs (leaves, hypocotyls, stem and roots) in order to determine the production of fresh and dry weight of all the organs, as well as the length of the stem and roots and number of leaves.

\section{Membrane permeability}

This parameter was included in order to have more information on the membrane stability and there by the relative ion content in the apoplastic space. Each organ of treated plants was washed with deionised water and were placed in closed vials containing $100 \mathrm{ml}$ of distilled water and incubated at $25^{\circ} \mathrm{C}$ for $3 \mathrm{hr}$; subsequently electrical conductivity of the solution (Lt) was determined. Samples were then autoclaved at $120^{\circ} \mathrm{C}$ for $20 \mathrm{~min}$ and the last electrical conductivity (L0) was obtained after equilibration at $25^{\circ} \mathrm{C}$. The electrolyte leakage $(\%)$ was defined as follows: $\left(\mathrm{L}_{\mathrm{t}} / \mathrm{L}_{0}\right) \times 100$.

\section{Mineral analysis}

Plant tissue samples were dried at $70{ }^{\circ} \mathrm{C}$ for $48 \mathrm{hr}$ and finely ground. Minerals were extracted with diluted nitric acid. Sodium and potassium concentrations of extracts were determined using a flame photometer and chloride using a chloridimeter.

\section{Data analysis}

The layout of the experiment was in a complete randomised design. The data were subjected to SAS analysis to check the significance. 


\section{RESULTS}

\section{Effects of salt stress on seed germination and viability}

The experimental data are presented in Figure 1. At the control level, all provenances displayed high levels of seed germination, around 95\%. Germination percentage of castor provenances was not strongly affected by all salinity levels. So increased salt concentration caused a lithely decrease in final germination percentage. Besides germination percentages of Ricinus communis were significantly different between treatments (Fig. 1) and were negatively correlated with salinity. $2 \mathrm{~g} / \mathrm{l}$ has not a significant effect on germination of Ricinus communis seeds. Figure 1 showed a very high germination percentage for the two salinity treatments 2 and $5 \mathrm{~g} / \mathrm{l}$. This observation is similar for the three tested genotypes. The percentage of germination is over $50 \%$ for the highest concentration $(10 \mathrm{~g} / \mathrm{l} \mathrm{NaCl})$ compared to control that exceeds $90 \%$ of germinated seeds. The interaction between provenances and salt stress was not significant. It should be noted that Sidi Thabet seeds under $2 \mathrm{~g} / \mathrm{l} \mathrm{NaCl}$ present a germination rate about $100 \%$, whereas it was about $97.78 \%$ for the control. Increasing duration time of seeds treated by salt significantly reduced the germination percentage. Based on the order of decreasing salt tolerance for seed germination after salt treatment, the genotype Grombalia had higher germination percentage than other genotypes, while Kairouan had the lowest germination percentage (Fig. 1). The results showed also that the germination's response of the three tested provenances has considerable differences in the timing of initiation and completion of germination (Fig. 2A, B, C).

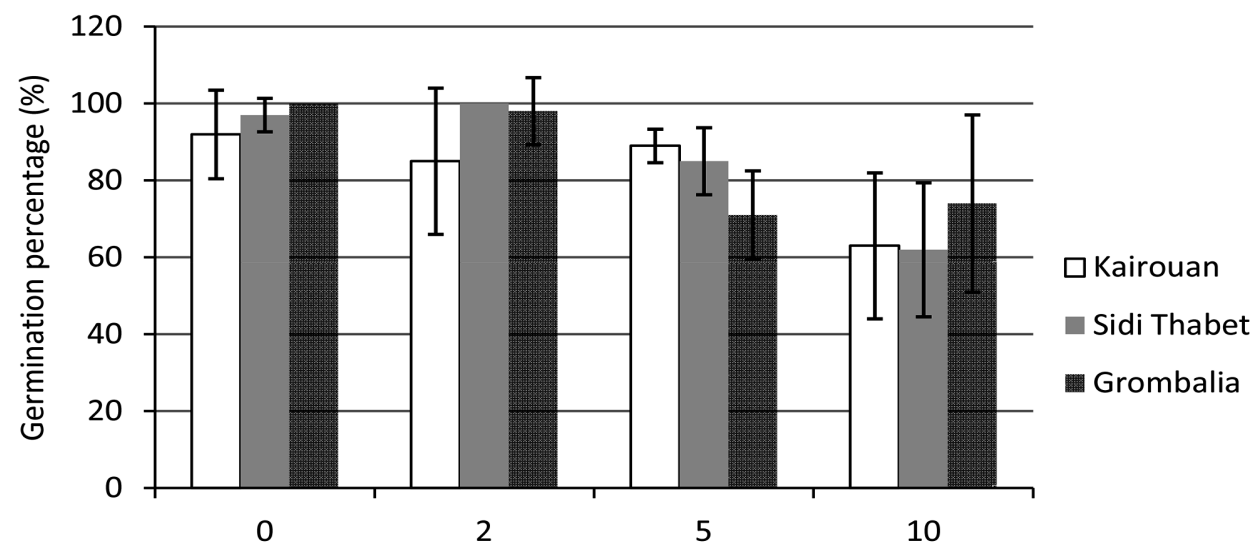

Fig. 1. Germination percentage of castor provenances as influenced by salinity levels after 45 days of culture. Each average value represents the mean of three replications 

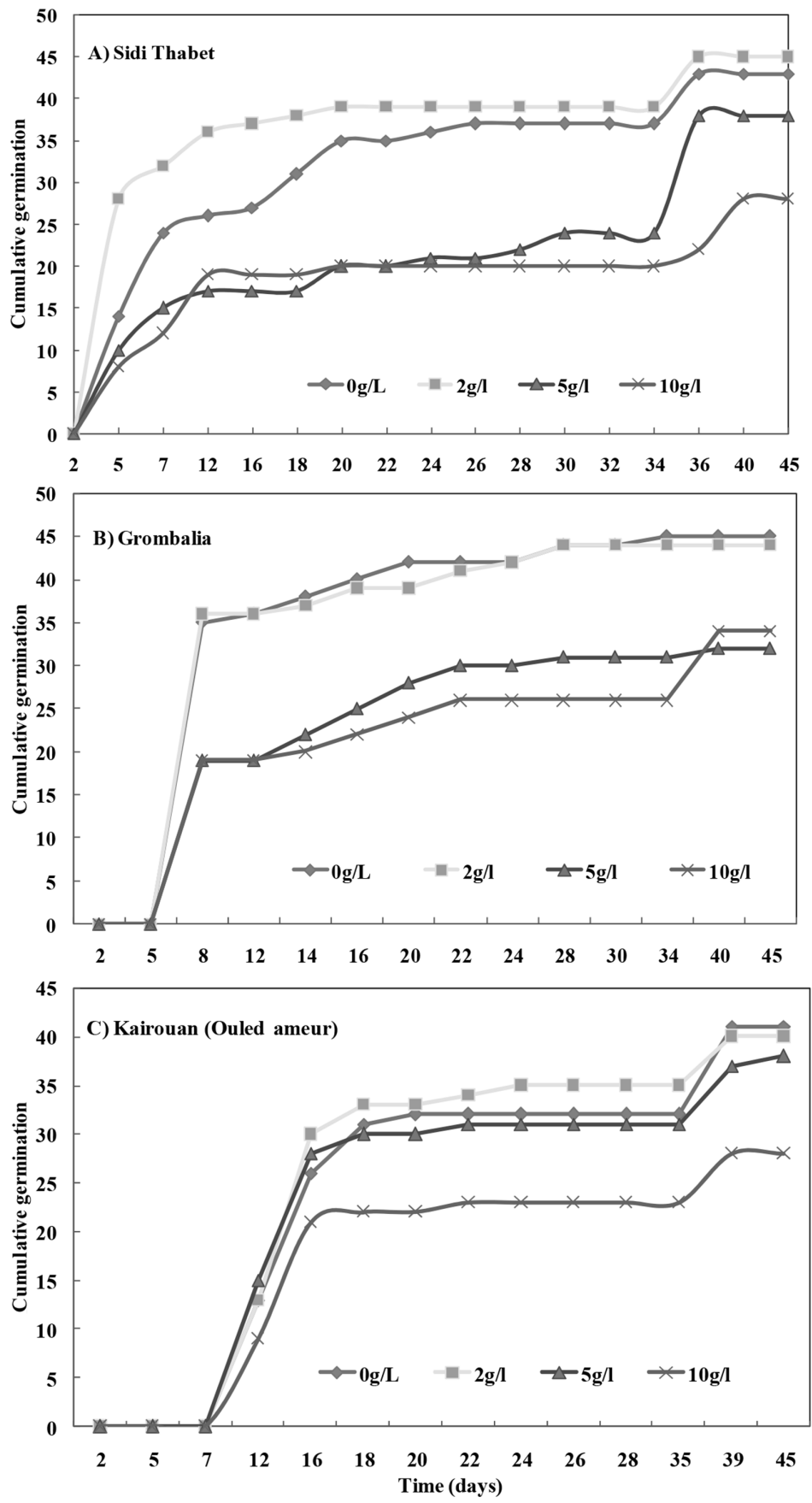

Fig. 2. Germination kinetics of castor provenances to different salt concentrations 
Table 2

MTG of seeds of three castor bean provenances under salinity treatments $(\mathrm{NaCl})$

\begin{tabular}{lcccc}
\hline & $0 \mathrm{~g} / \mathrm{l}$ & $2 \mathrm{~g} / \mathrm{l}$ & $5 \mathrm{~g} / \mathrm{l}$ & $10 \mathrm{~g} / \mathrm{l}$ \\
\hline Sidi Thabet & 12.77 & 10.5 & 17.53 & 10.9 \\
Kairouan & 18.4 & 16.14 & 16.04 & 8.87 \\
Grombalia & 9.4 & 9.65 & 9.43 & 11.8 \\
\hline
\end{tabular}

The curves are sigmoidal with 3 phases: latency, exponential and a stationary phase. Concerning Sidi Thabet, germination started within 2 days and was complete in the 44th day for the $4 \mathrm{NaCl}$ treatments. However, seed germination percentage decreased up to $62.2 \%$ as the level of salinity increased $(10 \mathrm{~g} / \mathrm{l}$ of $\mathrm{NaCl})$. Figure $2 \mathrm{~A}$ indicates that number of Sidi Thabet germinated seeds decreased comparatively over time especially at high salt treatments. For Grombalia, germination started within 5 days and was complete on the 45 th day for the 4 treatments. Figure 2B shows that germination kinetics of castor seeds of Grombalia was affected by 5 and $10 \mathrm{~g} / \mathrm{l}$ of NaCl more than $2 \mathrm{~g} / \mathrm{l}$. There is no significant difference between germination rate of seeds treated by $0 \mathrm{~g} / \mathrm{l}$ and $2 \mathrm{~g} / \mathrm{l}$, which is the case for 5 and $10 \mathrm{~g} / \mathrm{l}$. Also for Kairouan, the germination started within 7 days and was complete on the 45th day for the 4 treatments and germination rate of seeds treated with $5 \mathrm{~g} / 1$ tends to $91.8 \%$ for the control and $88.8 \%$ for $5 \mathrm{~g} / \mathrm{l}$. So the effect of salt stress on germination was weakly pronounced in the case of castor bean for the three provenances compared to control.

\section{Effect of salt stress on growth}

Growth. Salt stress induced significant differences on plant growth during the experimental period. After 80 days of $\mathrm{NaCl}$ treatment, decreases in plant height were observed. The treatment of $10 \mathrm{~g} / \mathrm{l} \mathrm{NaCl}$ has an intense depressive effect on seedling stage. The seedlings have not completed their development and this is obvious for all provenances. The treatment of $5 \mathrm{~g} / \mathrm{l} \mathrm{NaCl}$ has also an intense depressive effect only for Grombalia.

Leaf number. Number of leaves was affected by salinity. It was reduced during the treatments. There is not a significant difference between $0 \mathrm{~g} / \mathrm{l}$ and

Table 3

Coefficient of velocity values of seeds of three castor bean provenances treated with salt

\begin{tabular}{lcccc}
\hline & $0 \mathrm{~g} / 1$ & $2 \mathrm{~g} / 1$ & $5 \mathrm{~g} / 1$ & $10 \mathrm{~g} / \mathrm{l}$ \\
\hline Sidi Thabet & 325.04 & 354.24 & 229.89 & 188.67 \\
Kairouan & 211.87 & 202.36 & 221.18 & 149.71 \\
Grombalia & 279.18 & 274.22 & 191.11 & 177.11 \\
\hline
\end{tabular}


$2 \mathrm{~g} / \mathrm{l}$, which is not the case for $5 \mathrm{~g} / \mathrm{l} \mathrm{NaCl}$, which reduced significantly the number of leaves compared to control. Also, the control plants of Kairouan provenance maintain the same number of leaves that of $2 \mathrm{~g} / \mathrm{l} \mathrm{NaCl}$.

Shoot length. Increasing $\mathrm{NaCl}$ resulted in a decrease in shoot length. For Grombalia, no plant was able to grow shoot at $5 \mathrm{~g} / \mathrm{l}$; and at $10 \mathrm{~g} / \mathrm{l}$, no provenance was able to grow. Kairouan provenance presents the longest shoot for all $\mathrm{NaCl}$ levels. So shoot length was severely influenced by salt stress, but inhibition was greater at $10 \mathrm{~g} / \mathrm{l} \mathrm{NaCl}$. Salt stress depressed the shoot growth of Ricinus communis than their growth. Thus, shoot length diminished with increasing salinity levels in all provenances.

Hypocotyl length. Salinity had less effect on hypocotyl length. However, increasing salinity slightly reduced hypocotyl length.

Root length. Length of root is one of the most important characters for salt stress because roots are in contact with soil and thus absorb water from it. For this reason, root length provides an important clue to the response of plants to salt stress. Among the provenances, the longest root length was determined in Kairouan at $5 \mathrm{~g} / \mathrm{l} \mathrm{NaCl}$ with $10.11 \mathrm{~cm}$, while Grombalia could not develop the roots at this concentration. Generally, increasing salinity levels decreased the root length, and Sidi Thabet exhibited the greater performance in respect to root length. The rate of decline in root length for the provenances was more apparent in Grombalia. So $\mathrm{NaCl}$ had no high significant effects on root length either among treatments or among provenances. Root length is less sensitive to $\mathrm{NaCl}$ level than shoot length and leaf number. So, Grombalia was the most susceptible to high $\mathrm{NaCl}$ stress since its root growth was the lowest at $5 \mathrm{~g} / \mathrm{l}$ $\mathrm{NaCl}(0 \mathrm{~cm})$.

Dry weight. Fresh weight (FW) and dry weight (DW) of leaves, stems and roots of each plant were determined after counting the leaf number. The measurement of dry weight showed highly significant differences among organs. Therefore, the dry weight of organs was reduced through $\mathrm{NaCl}$ levels compared to control and this is observed for all provenances. Increasing salinity levels caused decreases in shoot dry weight. Although the provenances showed different responses to each salinity level, the highest values in all salinity levels were usually obtained from Kairouan except for $10 \mathrm{~g} / \mathrm{l} \mathrm{NaCl}$. As expected, salt levels had a significant effect on the shoot dry weight of all provenances. Salt concentrations resulted in a decline of both shoot length and shoot dry weight. Decreasing shoot dry weight resulted in the decline of shoot length in all provenances, but the reduction, which occurred for Kairouan was lower than that for Grombalia. The application of the salt stress caused a significant decrease of the production of dry weight of leaves in all tested provenances (Table 4) and especially in Grombalia and Kairouan. While the provenance Sidi Thabet had no significant decrease at dry leaves. 
Root dry weight diminished drastically with increasing salinity levels, as seen in Table 4. The dry weight of the roots of the provenances declined as root length fell, but the decline of root dry weight was lower than that of root length. In all salinity levels, Kairouan gave the highest root dry weight, while the lowest values were determined for Grombalia (at $5 \mathrm{~g} / \mathrm{l} \mathrm{NaCl}$ ). The decline in root dry weight between the control and final salinity levels was the lowest for Kairouan with $34.57 \%$, while the highest reduction was determined for Sidi Thabet with $87.82 \%$. The provenances could tolerate soil salinity levels up to $5 \mathrm{~g} / \mathrm{l}$ in terms of root dry weight, because a decreasing rate occurring between 2 and $5 \mathrm{~g} / \mathrm{l}$ was considered negligible. However, at higher doses the root dry matter and salt tolerance levels of the provenances dropped. In the study, the roots of Kairouan, which gave the highest values in respect to both root length and root dry weight, grew better under saline conditions. Castor provenances investigated in the first development stage showed different responses to the salinity levels applied in terms of root/shoot dry weight ratio. Generally, the ratio declined with increasing salinity levels, which showed that a greater reduction in root dry matter occurred rather than in shoot dry weight. On the other hand, it means that the roots were more adversely affected than shoots by salinity. Among the provenances, Kairouan gave a higher root/shoot dry weight ratio at all salinity levels except at $10 \mathrm{~g} / \mathrm{l} \mathrm{NaCl}$. It was also observed that Kairouan attained higher values at the second salinity level than the first salinity level. Basically, dry weights decreased as shoot and root length declined after salinity levels increased. In our study, the castor provenances we used could keep up with the soil salinity up to $5 \mathrm{~g} / \mathrm{l} \mathrm{NaCl}$ during the emergence and early growth stages, though, both the emergence percentage and shoot growth fell at higher salinity levels. In addition, root dry weight salt stress index decreased at salinity levels higher than $5 \mathrm{~g} / \mathrm{l} \mathrm{NaCl}$. In conclusion, within the emergence and seedling growth stages, there were differences between the provenances for salt tolerance; Kairouan was more resistant to high salt concentrations than the other provenances, while Grombalia was the most susceptible. Moreover, the roots of the castor appear more sensitive than the shoots.

Relative water content. The leaf hydration was not significantly affected by salinity. At the highest salt level $(5 \mathrm{~g} / \mathrm{l}$ of $\mathrm{NaCl})$, leaf water content remained at $80 \%$ of the control value. Similarly, the root water content was not impaired by this high salinity level.

Electrolyte leakage. The presence of $\mathrm{NaCl}$ in the nutritive solution induced a decrease in subsequent electrolyte leakage, as shown in Table 4 for salt-sensitive provenance Grombalia and salt-resistant Kairouan. Electrolyte leakage in leaves was not severely affected by salinity. So we noticed a slight reduction while increasing salinity for all the provenances compared to control. 


\section{Table 4}

Effects of salinity levels on growth ( $\mathrm{L}=$ length) (A), electrolyte leakage (EL) (B), dry weight (DW) (C), (D) and relative water content (WC) (E) of castor provenances

\begin{tabular}{|c|c|c|c|c|c|}
\hline & & & Sidi Thabet & Kairouan & Grombalia \\
\hline \multirow{12}{*}{$\mathrm{A}$} & \multirow{3}{*}{ leaf number } & $0 \mathrm{~g} / 1$ & 4.53 & 3.93 & 4.00 \\
\hline & & $2 \mathrm{~g} / 1$ & 3.63 & 3.92 & 3.83 \\
\hline & & $5 \mathrm{~g} / 1$ & 2.37 & 2.69 & 0.00 \\
\hline & \multirow{3}{*}{ shoot length $(\mathrm{cm})$} & $0 \mathrm{~g} / \mathrm{l}$ & 4.09 & 8.15 & 5.36 \\
\hline & & $2 \mathrm{~g} / 1$ & 2.75 & 3.71 & 3.84 \\
\hline & & $5 \mathrm{~g} / 1$ & 1.20 & 1.95 & 0.00 \\
\hline & \multirow{3}{*}{ hypocotyl length (cm) } & $0 \mathrm{~g} / 1$ & 14.62 & 16.94 & 11.09 \\
\hline & & $2 \mathrm{~g} / 1$ & 14.16 & 14.33 & 10.11 \\
\hline & & $5 \mathrm{~g} / 1$ & 10.87 & 11.27 & 0.00 \\
\hline & \multirow{3}{*}{ root length $(\mathrm{cm})$} & $0 \mathrm{~g} / 1$ & 11.72 & 11.88 & 11.68 \\
\hline & & $2 \mathrm{~g} / 1$ & 10.01 & 10.07 & 10.67 \\
\hline & & $5 \mathrm{~g} / 1$ & 9.59 & 10.12 & 0.00 \\
\hline \multirow{15}{*}{ B } & \multirow{3}{*}{ leaf EL (\%) } & $0 \mathrm{~g} / \mathrm{l}$ & 94.84 & 94.91 & 91.27 \\
\hline & & $2 \mathrm{~g} / 1$ & 94.84 & 90.93 & 83.80 \\
\hline & & $5 \mathrm{~g} / 1$ & 86.84 & 85.01 & 0.00 \\
\hline & \multirow{3}{*}{ shoot EL (\%) } & $0 \mathrm{~g} / \mathrm{l}$ & 91.09 & 88.36 & 87.70 \\
\hline & & $2 \mathrm{~g} / 1$ & 84.99 & 84.68 & 90.18 \\
\hline & & $5 \mathrm{~g} / 1$ & 73.01 & 79.99 & 0.00 \\
\hline & \multirow{3}{*}{ cotyledon EL (\%) } & $0 \mathrm{~g} / 1$ & 90.38 & 86.26 & 83.09 \\
\hline & & $2 \mathrm{~g} / \mathrm{l}$ & 86.90 & 69.54 & 86.26 \\
\hline & & $5 \mathrm{~g} / 1$ & 75.17 & 61.27 & 0.00 \\
\hline & \multirow{3}{*}{ hypocotyl EL (\%) } & $0 \mathrm{~g} / \mathrm{l}$ & 95.53 & 93.68 & 93.74 \\
\hline & & $2 \mathrm{~g} / 1$ & 92.30 & 92.58 & 93.76 \\
\hline & & $5 \mathrm{~g} / 1$ & 93.70 & 88.79 & 0.00 \\
\hline & \multirow{3}{*}{ root EL (\%) } & $0 \mathrm{~g} / 1$ & 83.20 & 77.56 & 75.69 \\
\hline & & $2 \mathrm{~g} / 1$ & 76.44 & 65.32 & 65.59 \\
\hline & & $5 \mathrm{~g} / 1$ & 73.55 & 51.31 & 0.00 \\
\hline \multirow{6}{*}{ C } & \multirow{3}{*}{ leaf DW (g) } & $0 \mathrm{~g} / \mathrm{l}$ & 0.14 & 0.33 & 0.41 \\
\hline & & $2 \mathrm{~g} / 1$ & 0.12 & 0.22 & 0.24 \\
\hline & & $5 \mathrm{~g} / 1$ & 0.02 & 0.08 & 0.00 \\
\hline & \multirow{3}{*}{ root DW $(\mathrm{g})$} & $0 \mathrm{~g} / \mathrm{l}$ & 0.21 & 0.50 & 0.45 \\
\hline & & $2 \mathrm{~g} / 1$ & 0.19 & 0.36 & 0.21 \\
\hline & & $5 \mathrm{~g} / 1$ & 0.03 & 0.33 & 0.00 \\
\hline
\end{tabular}




\begin{tabular}{|c|c|c|c|c|c|}
\hline \multicolumn{6}{|c|}{ Table 4 (continued) } \\
\hline & & & Sidi Thabet & Kairouan & Grombalia \\
\hline \multirow{6}{*}{$\mathrm{C}$} & \multirow{3}{*}{ shoot DW (g) } & $0 \mathrm{~g} / \mathrm{l}$ & 0.03 & 0.09 & 0.10 \\
\hline & & $2 \mathrm{~g} / \mathrm{l}$ & 0.02 & 0.10 & 0.07 \\
\hline & & $5 \mathrm{~g} / 1$ & 0.02 & 0.04 & 0.00 \\
\hline & \multirow{3}{*}{ shoot/root DW } & $0 \mathrm{~g} / \mathrm{l}$ & 0.15 & 0.18 & 0.23 \\
\hline & & $2 \mathrm{~g} / \mathrm{l}$ & 0.10 & 0.27 & 0.34 \\
\hline & & $5 \mathrm{~g} / 1$ & 0.70 & 0.11 & 0.00 \\
\hline \multirow{3}{*}{$\mathrm{D}$} & \multirow{3}{*}{ total DW (g) } & $0 \mathrm{~g} / \mathrm{l}$ & 0.71 & 1.38 & 1.34 \\
\hline & & $2 \mathrm{~g} / \mathrm{l}$ & 0.57 & 1.10 & 1.41 \\
\hline & & $5 \mathrm{~g} / 1$ & 0.21 & 0.72 & 0.00 \\
\hline \multirow{6}{*}{$\mathrm{E}$} & \multirow{3}{*}{ leaf WC (\%) } & $0 \mathrm{~g} / \mathrm{l}$ & 90.95 & 85.08 & 81.05 \\
\hline & & $2 \mathrm{~g} / 1$ & 88.68 & 84.68 & 80.68 \\
\hline & & $5 \mathrm{~g} / 1$ & 89.34 & 89.54 & 0.00 \\
\hline & \multirow{3}{*}{ root $\mathrm{WC}(\%)$} & $0 \mathrm{~g} / \mathrm{l}$ & 89.44 & 88.71 & 81.06 \\
\hline & & $2 \mathrm{~g} / 1$ & 91.17 & 86.93 & 88.53 \\
\hline & & $5 \mathrm{~g} / 1$ & 96.82 & 83.49 & 0.00 \\
\hline
\end{tabular}

For $2 \mathrm{~g} / \mathrm{l} \mathrm{NaCl}$, Sidi Thabet presented the highest percentage (94.84\%) and Grombalia presented the lowest percentage (83.79\%). Moreover, Sidi Thabet presented the highest percentage at $5 \mathrm{~g} / \mathrm{l} \mathrm{NaCl}(86.84 \%)$. Electrolyte leakage in shoots was reduced through salinity levels. Sidi Thabet presented $73 \%$ at $5 \mathrm{~g} / 1$ $\mathrm{NaCl}$, which is $91.08 \%$ for the control. Sidi Thabet presents also the highest percentage $91.09 \%$ for control. However, Kairouan presented the highest electrolyte leakage at $5 \mathrm{~g} / \mathrm{l} \mathrm{NaCl}(79.99 \%)$. Electrolyte leakage in cotyledons was also reduced by salinity. In fact, the figures showed the highest percentage $(90.38 \%)$ for Sidi Thabet at $0 \mathrm{~g} / \mathrm{l} \mathrm{NaCl}$ and the lowest percentage $(61.27 \%)$ for Kairouan at $5 \mathrm{~g} / \mathrm{l} \mathrm{NaCl}$. Electrolyte leakage of hypocotyls was not affected by $2 \mathrm{~g} / \mathrm{l}$ for all provenances. We noticed a slight reduction of electrolyte leakage for Kairouan at $5 \mathrm{~g} / \mathrm{l} \mathrm{NaCl}(88.79 \%)$ compared to control $(93.67 \%)$. Electrolyte leakage of roots was reduced by salinity. So, it showed highly significant difference through $\mathrm{NaCl}$ treatment. Thus, Sidi Thabet presented the highest percentage $(83.19 \%$ ) for control, which was reduced to $73.54 \%$ for $5 \mathrm{~g} / \mathrm{l} \mathrm{NaCl}$. Also, electrolyte leakage of Kairouan roots was significantly reduced at $5 \mathrm{~g} / 1$ $\mathrm{NaCl}$ to $51.30 \%$, compared to control (77.55\%). 
Table 5

Effect of salinity stress on mineral nutrition of different organs of Ricinus communis seedlings (A, B, C, D and E)

\begin{tabular}{|c|c|c|c|c|c|}
\hline & & & Sidi Thabet & Kairouan & Grombalia \\
\hline \multirow{12}{*}{$\begin{array}{l}(\mathrm{A}) \\
\text { Leaf }\end{array}$} & \multirow{3}{*}{$\begin{array}{c}\mathrm{Na}^{+} \\
(\mathrm{meq} / \mathrm{g} \mathrm{DW})\end{array}$} & $0 \mathrm{~g} / \mathrm{l}$ & 4.37 & 5.05 & 3.93 \\
\hline & & $2 \mathrm{~g} / 1$ & 5.18 & 5.46 & 3.98 \\
\hline & & $5 \mathrm{~g} / 1$ & 5.97 & 8.00 & 0.00 \\
\hline & \multirow{3}{*}{$\begin{array}{c}\mathrm{Cl}^{-} \\
(\mathrm{meq} / \mathrm{g} \mathrm{DW})\end{array}$} & $0 \mathrm{~g} / \mathrm{l}$ & 0.00 & 0.00 & 0.00 \\
\hline & & $2 \mathrm{~g} / 1$ & 0.67 & 0.57 & 0.70 \\
\hline & & $5 \mathrm{~g} / 1$ & 1.70 & 0.62 & 0.00 \\
\hline & \multirow{3}{*}{$\begin{array}{c}\mathrm{K}^{+} \\
(\mathrm{meq} / \mathrm{g} \mathrm{DW})\end{array}$} & $0 \mathrm{~g} / \mathrm{l}$ & 7.88 & 8.36 & 9.39 \\
\hline & & $2 \mathrm{~g} / 1$ & 7.63 & 9.83 & 9.32 \\
\hline & & $5 \mathrm{~g} / 1$ & 6.96 & 7.32 & 0.00 \\
\hline & \multirow{3}{*}{$\mathrm{Na}^{+} / \mathrm{K}^{+}$} & $0 \mathrm{~g} / \mathrm{l}$ & 0.55 & 0.60 & 0.42 \\
\hline & & $2 \mathrm{~g} / 1$ & 0.68 & 0.56 & 0.43 \\
\hline & & $5 \mathrm{~g} / 1$ & 0.86 & 1.09 & 0.00 \\
\hline \multirow{12}{*}{$\begin{array}{l}\text { (B) } \\
\text { Shoot }\end{array}$} & \multirow{3}{*}{$\begin{array}{c}\mathrm{Na}^{+} \\
(\mathrm{meq} / \mathrm{g} \mathrm{DW})\end{array}$} & $0 \mathrm{~g} / \mathrm{l}$ & 7.63 & 4.90 & 6.81 \\
\hline & & $2 \mathrm{~g} / 1$ & 11.48 & 9.72 & 9.37 \\
\hline & & $5 \mathrm{~g} / 1$ & 11.20 & 12.86 & 0.00 \\
\hline & \multirow{3}{*}{$\begin{array}{c}\mathrm{Cl}^{-} \\
(\mathrm{meq} / \mathrm{g} \mathrm{DW})\end{array}$} & $0 \mathrm{~g} / \mathrm{l}$ & 0.00 & 0.00 & 0.00 \\
\hline & & $2 \mathrm{~g} / 1$ & 1.93 & 2.00 & 2.24 \\
\hline & & $5 \mathrm{~g} / 1$ & 2.43 & 1.59 & 0.00 \\
\hline & \multirow{3}{*}{$\begin{array}{c}\mathrm{K}^{+} \\
(\mathrm{meq} / \mathrm{g} \mathrm{DW})\end{array}$} & $0 \mathrm{~g} / \mathrm{l}$ & 22.56 & 17.83 & 13.42 \\
\hline & & $2 \mathrm{~g} / 1$ & 21.32 & 25.24 & 17.79 \\
\hline & & $5 \mathrm{~g} / 1$ & 18.41 & 14.72 & 0.00 \\
\hline & \multirow{3}{*}{$\mathrm{Na}^{+} / \mathrm{K}^{+}$} & $0 \mathrm{~g} / \mathrm{l}$ & 0.34 & 0.55 & 0.51 \\
\hline & & $2 \mathrm{~g} / 1$ & 0.54 & 0.51 & 0.53 \\
\hline & & $5 \mathrm{~g} / 1$ & 0.61 & 0.33 & 0.00 \\
\hline \multirow{9}{*}{$\begin{array}{l}\text { (C) } \\
\text { Cotyledon }\end{array}$} & \multirow{3}{*}{$\begin{array}{c}\mathrm{Na}^{+} \\
(\mathrm{meq} / \mathrm{g} \mathrm{DW})\end{array}$} & $0 \mathrm{~g} / \mathrm{l}$ & 6.88 & 7.75 & 6.35 \\
\hline & & $2 \mathrm{~g} / 1$ & 8.00 & 8.50 & 8.33 \\
\hline & & $5 \mathrm{~g} / 1$ & 9.19 & 9.48 & 0.00 \\
\hline & \multirow{3}{*}{$\begin{array}{c}\mathrm{Cl}^{-} \\
(\mathrm{meq} / \mathrm{g} \mathrm{DW})\end{array}$} & $0 \mathrm{~g} / \mathrm{l}$ & 0.00 & 0.00 & 0.00 \\
\hline & & $2 \mathrm{~g} / 1$ & 1.33 & 1.18 & 2.57 \\
\hline & & $5 \mathrm{~g} / 1$ & 2.25 & 2.51 & 0.00 \\
\hline & \multirow{3}{*}{$\begin{array}{c}\mathrm{K}^{+} \\
(\mathrm{meq} / \mathrm{g} \mathrm{DW})\end{array}$} & $0 \mathrm{~g} / \mathrm{l}$ & 14.08 & 13.65 & 13.74 \\
\hline & & $2 \mathrm{~g} / 1$ & 11.73 & 15.81 & 12.97 \\
\hline & & $5 \mathrm{~g} / 1$ & 11.94 & 15.10 & 0.00 \\
\hline
\end{tabular}


Table 5 (continued)

\begin{tabular}{|c|c|c|c|c|c|}
\hline & & & Sidi Thabet & Kairouan & Grombalia \\
\hline \multirow{3}{*}{$\begin{array}{l}\text { (C) } \\
\text { Cotyledon }\end{array}$} & \multirow{3}{*}{$\mathrm{Na}^{+} / \mathrm{K}^{+}$} & $0 \mathrm{~g} / 1$ & 0.49 & 0.57 & 0.46 \\
\hline & & $2 \mathrm{~g} / 1$ & 0.68 & 0.54 & 0.64 \\
\hline & & $5 \mathrm{~g} / 1$ & 0.77 & 0.63 & 0.00 \\
\hline \multirow{12}{*}{$\begin{array}{l}\text { (D) } \\
\text { Hypocotyl }\end{array}$} & \multirow{3}{*}{$\begin{array}{c}\mathrm{Na}^{+} \\
(\mathrm{meq} / \mathrm{g} \mathrm{DW})\end{array}$} & $0 \mathrm{~g} / 1$ & 7.11 & 7.28 & 5.61 \\
\hline & & $2 \mathrm{~g} / 1$ & 12.76 & 10.07 & 9.99 \\
\hline & & $5 \mathrm{~g} / 1$ & 20.40 & 17.99 & 0.00 \\
\hline & \multirow{3}{*}{$\begin{array}{c}\mathrm{Cl}^{-} \\
(\mathrm{meq} / \mathrm{g} \mathrm{DW})\end{array}$} & $0 \mathrm{~g} / \mathrm{l}$ & 0.00 & 0.00 & 0.00 \\
\hline & & $2 \mathrm{~g} / 1$ & 2.36 & 2.09 & 2.59 \\
\hline & & $5 \mathrm{~g} / 1$ & 4.46 & 3.95 & 0.00 \\
\hline & \multirow{3}{*}{$\begin{array}{c}\mathrm{K}^{+} \\
(\mathrm{meq} / \mathrm{g} \mathrm{DW})\end{array}$} & $0 \mathrm{~g} / 1$ & 14.02 & 17.00 & 20.37 \\
\hline & & $2 \mathrm{~g} / 1$ & 11.77 & 17.35 & 17.29 \\
\hline & & $5 \mathrm{~g} / 1$ & 10.56 & 12.52 & 0.00 \\
\hline & \multirow{3}{*}{$\mathrm{Na}^{+} / \mathrm{K}^{+}$} & $0 \mathrm{~g} / 1$ & 0.51 & 0.43 & 0.28 \\
\hline & & $2 \mathrm{~g} / 1$ & 1.08 & 0.58 & 0.58 \\
\hline & & $5 \mathrm{~g} / 1$ & 1.93 & 1.44 & 0.00 \\
\hline \multirow{12}{*}{$\begin{array}{l}\text { (E) } \\
\text { Root }\end{array}$} & \multirow{3}{*}{$\begin{array}{c}\mathrm{Na}^{+} \\
(\mathrm{meq} / \mathrm{g} \mathrm{DW})\end{array}$} & $0 \mathrm{~g} / 1$ & 4.50 & 3.92 & 3.37 \\
\hline & & $2 \mathrm{~g} / 1$ & 6.57 & 3.98 & 5.47 \\
\hline & & $5 \mathrm{~g} / 1$ & 9.99 & 4.90 & 0.00 \\
\hline & \multirow{3}{*}{$\begin{array}{c}\mathrm{Cl}^{-} \\
(\mathrm{meq} / \mathrm{g} \mathrm{DW})\end{array}$} & $0 \mathrm{~g} / 1$ & 0.00 & 0.00 & 0.00 \\
\hline & & $2 \mathrm{~g} / 1$ & 1.30 & 0.68 & 1.74 \\
\hline & & $5 \mathrm{~g} / 1$ & 2.42 & 0.88 & 0.00 \\
\hline & \multirow{3}{*}{$\begin{array}{c}\mathrm{K}^{+} \\
(\mathrm{meq} / \mathrm{g} \mathrm{DW})\end{array}$} & $0 \mathrm{~g} / 1$ & 6.27 & 4.13 & 4.86 \\
\hline & & $2 \mathrm{~g} / 1$ & 5.05 & 2.97 & 4.13 \\
\hline & & $5 \mathrm{~g} / 1$ & 8.84 & 3.87 & 0.00 \\
\hline & \multirow{3}{*}{$\mathrm{Na}^{+} / \mathrm{K}^{+}$} & $0 \mathrm{~g} / 1$ & 0.72 & 0.95 & 0.69 \\
\hline & & $2 \mathrm{~g} / 1$ & 1.30 & 1.34 & 1.33 \\
\hline & & $5 \mathrm{~g} / 1$ & 1.13 & 1.27 & 0.00 \\
\hline
\end{tabular}

\section{Effect of salt stress on mineral nutrition}

Sodium. Sodium ion concentration in leaves increased through salinity levels, especially for Kairouan, which reached $8 \mathrm{meq} / \mathrm{g}$ DW at $5 \mathrm{~g} / \mathrm{l} \mathrm{NaCl} \mathrm{com-}$ pared to control (5.05 meq/g DW). Sodium content in stems increased through $\mathrm{NaCl}$ levels. However, Kairouan at $5 \mathrm{~g} / \mathrm{l} \mathrm{NaCl}$ presented the highest $\mathrm{Na}^{+}$concentration in stem (12.68 meq/g DW). $\mathrm{Na}^{+}$content in cotyledons increased lin- 
early with increases in $\mathrm{NaCl}$ levels reaching 9.19 meq/g DW at $5 \mathrm{~g} / \mathrm{l} \mathrm{NaCl}$ for Sidi Thabet and $9.48 \mathrm{meq} / \mathrm{g}$ DW for Kairouan compared to control having 6.88 meq/g DW and 7.75 meq/g DW, respectively. This was observed also for $\mathrm{Na}^{+}$ content in hypocotyls and roots for all provenances. The hypocotyls are more concentrated in $\mathrm{Na}^{+}$than the other organs. Moreover, Sidi Thabet and Kairouan presented the highest concentrations at $5 \mathrm{~g} / \mathrm{l} \mathrm{NaCl}$ reaching $20.40 \mathrm{meq} / \mathrm{g}$ DW and $17.99 \mathrm{meq} / \mathrm{g}$ DW, respectively.

Chloride. $\mathrm{Cl}^{-}$content in leaves increased linearly up to levels of $5 \mathrm{~g} / 1 \mathrm{NaCl}$. Kairouan presented a slight increase at $5 \mathrm{~g} / 1 \mathrm{NaCl}(0.62 \mathrm{meq} / \mathrm{g} \mathrm{DW})$ compared to $2 \mathrm{~g} / 1 \mathrm{NaCl}(0.57 \mathrm{meq} / \mathrm{g} \mathrm{DW})$, while chloride content in the leaves of Sidi Thabet was about 3-fold higher $(1.70 \mathrm{meq} / \mathrm{g} \mathrm{DW})$ than for $2 \mathrm{~g} / \mathrm{l} \mathrm{NaCl}(0.67$ meq/g DW). At $2 \mathrm{~g} / \mathrm{l} \mathrm{NaCl}$, Grombalia presented the highest $\mathrm{Cl}^{-}$content in leaves also for all organs. However, Kairouan presented the lowest $\mathrm{Cl}^{-}$content for all organs. For roots, it reached a minimal value $(0.88 \mathrm{meq} / \mathrm{g} D W)$. The hypocotyls stored also $\mathrm{Cl}^{-}$more than the other organs and it was observed for all the provenances.

Potassium. $\mathrm{K}^{+}$concentration generally decreased with an increase in the salt level. However, we observed a slight increase in $\mathrm{K}^{+}$concentration for 2 and $5 \mathrm{~g} / \mathrm{l} \mathrm{NaCl}$ compared to control, especially for Kairouan in stems (25.24 $\mathrm{meq} / \mathrm{g}$ DW at $2 \mathrm{~g} / \mathrm{l} \mathrm{NaCl}$, compared to control $17.83 \mathrm{meq} / \mathrm{g} \mathrm{DW}$ ).

$\mathrm{K}^{+}$and $\mathrm{Na}^{+}$selectivity ratios. It is an important physiological response to salinity stress that plants maintain a high concentration of $\mathrm{K}^{+}$and a low concentration of $\mathrm{Na}^{+}$in the cytoplasm (Tester and Davenport 2003); so $\mathrm{Na}^{+} / \mathrm{K}^{+}$ ratio decreased compared to control. In this study, $\mathrm{Na}^{+} / \mathrm{K}^{+}$rate presented difference between sources and organs. Leaves $\mathrm{Na}^{+} / \mathrm{K}^{+}$ratio was consistently increased in the ecotypes from Sidi Thabet and Kairouan with increase in salt level, whereas in plants from the Grombalia population this ratio was relatively less affected. Root $\mathrm{Na}^{+} / \mathrm{K}^{+}$ratio, on the other hand, gradually increased with increase in $\mathrm{NaCl}$. Values revealed a significant reduction in $\mathrm{Na}^{+} / \mathrm{K}^{+}$ratio in the ecotype of Kairouan at $5 \mathrm{~g} / \mathrm{l} \mathrm{NaCl}$ compared to the control.

\section{DISCUSSION}

Salinity stress can affect seed germination through osmotic effects (Welbaum et al. 1990) or by ion toxicity (Huang and Reddman 1995). In this context, the term salt stress during seed germination is used only to refer to situations where the seed germinates rapidly under salt stress conditions. No distinction is made between osmotic and ionic effects of salinity stress (Bayuelo-Jiménez et al. 2002). Our study indicated that the effect of salt stress on germination was weakly pronounced in the case of castor bean for the three provenances compared to control. Results showed that Sidi Thabet had 
a higher rate of germination of the stressed seeds at $2 \mathrm{~g} / \mathrm{l} \mathrm{NaCl}$ compared with non-stressed seeds. The stimulation of germination by salt was mentioned by many authors on several species such as the millet (Bouraïma et al. 1986, de Villèle 1965, Radhouane 2008). Moreover, the preliminary steeping of the seeds of many cultures in a salted solution increased their germination, the installation of the seedlings and, in some cases it stimulated the growth and the output (Ahmed et al. 1998, Ashraf et al. 2003). The response of the Ricinus communis provenances to $\mathrm{NaCl}$ treatment was variable during the early vegetative stage. These results indicate that the salt tolerance was differential. Salinity reduced seedlings growth because it reduced the ability of plants to utilise water (Munns 2002). Reductions in the biomass, membrane integrity and water content of Ricinus communis under saline condition were indicative to severe growth limitation at $10 \mathrm{~g} / \mathrm{l} \mathrm{NaCl}$. Salinity had adverse effects not only on these parameters, but also on other morphological parameters, such as plant height (stem and hypocotyl lengths), root length and number of leaves as found in several species, such as soybean (Glycine max) (Grattan and Maas 1988) and common bean (Phaseolus vulgaris) (Gamma et al. 2007). Ricinus communis was more tolerant during germination than seedling growth. These results are in agreement with reports on lentil (Ashraf and Waheed 1990), Hordeum spp. (Mano and Takeda 1998) and Phaseolus species (Bayuelo-Jiménez et al. 2002). These authors also demonstrated that salinity tolerance varies with plant ontogeny. Plants growing under saline conditions are stressed basically in three ways: 1) reduced water potential in the root zone causing water deficit, 2) phytoxicity of ions such as $\mathrm{Na}^{+}$and $\mathrm{Cl}^{-}$and 3) nutriment imbalance by depression in uptake and/or shoot transport (Marschner 1995). This is attributed to the fact that $\mathrm{Na}^{+}$competes with $\mathrm{K}^{+}$for binding sites that are essential for enzymatic and cellular functions (Tester and Davenport 2003). This role makes $\mathrm{K}^{+}$an important element as more than 50 enzymes are activated by $\mathrm{K}^{+}$, and $\mathrm{Na}^{+}$cannot substitute in this role (Bhandal and Malik 1988). The provenances which presented the highest ratios were most tolerant, and the most sensitive presented the weakest $\mathrm{K}^{+} / \mathrm{Na}^{+}$ratios. At many species of the Triticum genus, the foliar exclusion of $\mathrm{Na}^{+}$due to the limitation of its translocation of the roots towards the aerial parts and the $\mathrm{K}^{+} / \mathrm{Na}^{+}$selectivity of the leaves appear as mechanisms of tolerance to salt and constitute excellent varietal criteria of selection (Wyn Jones and Gorham 1989). Our results showed that $\mathrm{Na}^{+} / \mathrm{K}^{+}$ratio increased (especially for hypocotyls) through $\mathrm{NaCl}$ level and hypocotyls were more concentrated in $\mathrm{Na}^{+}$than the other organs. It seems that Ricinus communis has the capacity to store the toxic ions as $\mathrm{Na}^{+}$in the youthful organs, such as in hypocotyls and not in leaf (sites of photosynthesis). Some studies presented the role of the stem in this context, aiming at determining if this organ plays a role in $\mathrm{Na}^{+}$within the ascending way of the ion towards 
the sheets (leaves). The exclusion of $\mathrm{Na}^{+}$of the leaves of the sensitive plants to $\mathrm{NaCl}$ is associated to a specific accumulation of this ion in the stems. Because of their significant volume compared to the whole of the organs of the plant and their strong intrinsic capacity of accumulation, the stems take part obviously in the protection of the leaves against $\mathrm{Na}^{+}$(Hajji 1983, Jacoby 1965, Morard 1981, Rains 1969, Walker 1986). In this context, a study presented an incompatible result with this assumption that the stems protect the leaves against invasion by $\mathrm{Na}^{+}$by reabsorbing this ion starting from the sap from the xylem, and while functioning like traps for this ion (Slama 1991). So based on the stability of the tolerance to salinity from germinative stage to seedlings stage, the provenance of Kairouan was identified as the most tolerant and the provenance of Grombalia as the most sensitive to salt toxicity.

\section{REFERENCES}

Ahmed, S., Anwar M. and Ullah, H. (1998): Wheat seed pre-soaking for improved germination. - J. Agron. Crop Sci. 181: 125-127. doi: 10.1111/j.1439-037X.1998.tb00407.x

Allakhverdiev, S. I., Sakamoto, A., Nishiyama, Y., Inaba, M. and Murata, N. (2000): Ionic and osmotic effects of $\mathrm{NaCl}^{-}$induced inactivation of photosystems I and II in Synechococcus sp. - Plant Physiol. 123: 1047-1056. http://dx.doi.org/10.1104/pp.123.3.1047

Ashraf, M. (2004): Some important physiological selection criteria for salt tolerance in plants. - Flora 199: 361-376. http://dx.doi.org/10.1078/0367-2530-00165

Ashraf, M. and Waheed, A. (1990): Screening of local/exotic accessions of lentil (Lens culinaris) for salt tolerance at two growth stages. - Plant and Soil 128: 167-176. http:// dx.doi.org/10.1007/BF00011106

Ashraf, M., Kausar, A. and Ashraf, M. Y. (2003): Alleviation of salt stress in pear millet (Pennisetum glaucum (L.) R. Br.) through seed treatment. - Agronomie 23: 227-234. http://dx.doi.org/10.1051/agro:2002086

Bayuelo-Jiménez, J. S., Debouck, D. G. and Lynch, J. P. (2002): Salinity tolerance of Phaseolus species during germination and early seedling growth. - Crop Sci. 42: 1584-1594. http://dx.doi.org/10.2135/cropsci2002.1584

Ben Ahmed, H., Manaa, A. and Zid, E. (2008): Tolérance à la salinité d'une poaceae à cycle court: la sétaire (Setaria verticillata L.). - C. R. Biologies 331: 164-170. http://dx.doi. org/10.1016/j.crvi.2007.12.002

Bhandal, I. S. and Malik, C. P. (1988): Potassium estimation, uptake and its role in the physiology and metabolism of flowering plants. - Int. Rev. Cytol. 10: 205-224. http:// dx.doi.org/ 10.1016/S0074-7696(08)61851-3

Bouraïma, S., Lavergne, D., Champigny, M.-L. (1986): Étude comparée de la tolérance au sel de différents mil: croissance, activités phosphoénolpyruvate carboxylase et enzyme malique à NADP. - Agronomie 6(7): 675-682. http://dx.doi.org/10.1051/agro:19860710

de la Paz, J., Larionova, M., Maceira, M. A., Borrego, S. F. and Echevarria, E. (2006): Control of biodeterioration using a fraction isolated from leaves of Ricinus communis L. Pharmacologyonline 3: 462-466.

de Villèle, O. (1965): Cinq années d'expérience sur les besoins en eau des cultures. - Document Technique, Inst. Nat. Rech. Agron. de Tunisie, (11), 54 pp. 
Edwards, D. G. V. and Wang, B. S. P. (1995): A training guide for laboratory analysis of forest tree seeds. - Pacific Forestry Center, Information Report BC X-356, Canadian Forest Service, Canada, $64 \mathrm{pp}$.

Gamma, P. B. S., Inanaga, S., Tanaka, K. and Nakazawa, P. (2007): Physiological response of common bean (Phaseolus vulgaris L.) seedlings to salinity stress. - Afric. J. Biotechnol. 6(2): 79-88.

Grattan, S. R. and Maas, E. V. (1988): Effect of salinity on leaf P accumulation and injury in soybean. I. Influence of varying $\mathrm{CaCl}_{2} / \mathrm{NaCl}$ - Plant and Soil 105: 25-32. http://dx.doi. org/10.1007/BF02371139

Hajji, M. (1983): Mécanisme des effets du milieu salé sur la nutrition d'une plante ripicole. Interaction des transports d'ions et d'eau chez le laurier-rose. - Thèse Doct. Sci., Tunis, 278 pp.

Huang, J. and Reddman, R. E. (1995): Salt tolerance of Hordeum and Brassica species during germination and early growth. - Can. J. Plant Sci. 75: 815-819. http://dx.doi. org/10.4141/cjps95-137

Ilavarasan, R., Mallika, M. and Venkataraman, S. (2005): Anti-inflammatory and free radical scavenging activity of R. communis root extract. - J. Ethnopharmacol. 103(3): 478-480. http://dx.doi.org/10.1016/j.jep.2005.07.029

Jacoby, B. (1965): Sodium retention in excised bean stems. - Physiol. Plant. 18: 730-739. http://dx.doi.org/10.1111/j.1399-3054.1965.tb06932.x

Luseba, D., Elgorashi, E. E., Ntloedibe, D. T. and Van Staden, J. (2007): Antibacterial, antiinflammatory and mutagenic effects of some medicinal plants used in South Africa for the treatment of wounds and retained placenta in livestock. - S. Afr. J. Bot. 73: 378-383. http://dx.doi.org/10.1016/j.sajb.2007.03.003

Mano, Y. and Takeda, K. (1998): Genetic resources of salt tolerance in wild Hordeum species. - Euphytica 103: 137-141. http://dx.doi.org/10.1023/A:1018302910661

Mansour, M. M. F. and Salama, K. H. A. (2004): Cellular basis of salinity tolerance in plants. - Env. Exp. Bot. 52: 113-122. http://dx.doi.org/10.1016/j.envexpbot.2004.01.009

Marschner, H. (1995): Mineral nutrition of higher plants. 2n ed. - Academic Press, London.

Morard, P. (1981): Distribution du radiosodium absorbé par voie racinaire dans les différents organs de sorghos carencés ou non potassium. - CR Seances Acad. Sci. Paris, Ser. III, Sci. Vie 292: 1231-1236.

Munns, R. (2002): Comparative physiology of salt and water stress. - Plant Cell Environ. 25: 239-250. http://dx.doi.org/10.1046/j.0016-8025.2001.00808.x

Pinheiro, H. A., Silva, J. V., Endres, L., Marques Ferreirac, V., de Albuquerque Câmara, C., Cabral, F. F., Figueredo Oliveira, J., Wagner Torres de Carvalho, L., Messias dos Santos, J. and Gomes dos Santos Filho, B. (2008): Leaf gas exchange, chloroplastic pigments and dry matter accumulation in castor bean (Ricinus communis L.) seedlings subjected to salt stress conditions. - Industr. Crops and Products 27(3): 385-392. http:// dx.doi.org/ 10.1016/j.indcrop.2007.10.003

Radhouane, L. (2008): Effet du stress salin sur la germination, la croissance et la production en grains chez quelques écotypes de mil (Pennisetum glaucum (L.) R. Br.) autochtones de Tunisie. - C. R. Biologies 331: 278-286. http://dx.doi.org/10.1016/j.crvi.2008.01.006

Rains, D. W. (1969): Sodium and potassium absorption by bean stem. - Tissue Plant Physiol. 42: 1171-1175.

Slama, F. (1991): Transport de $\mathrm{Na}^{+}$dans les feuilles et sensibilité des plantes à NaCl: evolution d'un effet piège au niveau des tiges. - Agronomie 11: 275-281. http://dx.doi. org/10.1051/agro:19910404 
Tester, M. and Davenport, R. (2003): $\mathrm{Na}^{+}$tolerance and $\mathrm{Na}^{+}$transport in higher plants. Ann. Bot. 9: 503-527. http://dx.doi.org/10.1093/aob/mcg058

Walker, R. R. (1986): Sodium exclusion and potassium sodium selectivity in salt-treated trifoliate orange (Poncirus trifoliata) and Cleopatra mandarin (Citrus reticulata) plants. - Aust. J. Plant Physiol. 13: 293-303. http://dx.doi.org/10.1071/PP9860293

Weiss, E. A. (1983): Oilseed crops. - Longman, New York, 660 pp.

Welbaum, G. E., Tissaoui, T. and Bradford, K. J. (1990): Water relations of seed development and germination in muskmelon (Cucumis melo L.) III. Sensitivity of germination to water potential and abscisic acid during development. - Plant Physiol. 92: 1029-1037. http://dx.doi.org/10.1104/pp.92.4.1029

Wyn Jones, R. G. and Gorham, J. (1989): Use of physiological traits in breeding for salinity tolerance. - In: Baker, F. W. G. (ed.): Drought resistance in cereal. CAB international, Wallingford.

Xiong, L., Schumaker, K. S. and Zhu, J. K. (2002): Cell signalling during cold, drought, and salt stress. - Plant Cell 14(Suppl.): 165-183.

Yousheng, C. and Sziklai, O. (1985): Preliminary study on the germination of Toona sinensis (A. Juss.) Roem. Seed from eleven Chinese provenances. - For. Ecol. Manage. 10: 269-281. http://dx.doi.org/10.1016/0378-1127(85)90119-7 